\title{
CORROSION-EROSION WASTE OF METALS IN THE DUCT SYSTEM OF THE RECYCLING ALUMINIUM FURNACE
}

The corrosion aggressiveness of the environment in the recycling aluminium furnace duct system is very high. Temperature is in the range from 300 to $900{ }^{\circ} \mathrm{C}$ and chemical composition of combustion varies according to treated aluminium waste and flue gas flow is turbulent. These conditions are very complicated for construction metal selection. The aim of the work is to investigate corrosion-erosion behaviour of various construction metals in the operating conditions of the duct system. The metals with different chemical composition (unalloyed construction steel, stainless steel and nickel based alloy) were tested by long time experiment in the real work conditions of the recycling aluminium furnace. The character and intensity of the materials corrosion attack after one year exposition are evaluated by gravimetric and metallographic analysis.

Keywords: High temperature corrosion, fuel gas, recycling furnace, erosion

\section{Introduction}

The corrosion aggressiveness of the environment in the duct system of the recycling aluminium furnace is caused by fluctuation of combustion chemical composition. It is because aluminium waste contains remains of various materials (oxygen, carbon oxides, steam, sulphides, halides etc.). At high temperature can very diverse compounds can be created and it makes impossible to define chemical composition of environment. This fact very strong restricts choice of metal and prediction of their corrosion behaviour [1].

Corrosion rate of metals is expressly influenced by temperature and chemical composition of environment because both factors affect character of corrosion products. The average temperature throughout the duct system is from $800{ }^{\circ} \mathrm{C}$ to $300{ }^{\circ} \mathrm{C}$. The heat flux influences oxidation behaviour of metals. Fast oxidation produces thicker oxides with more pores and worsens adhesion [2-3]. The function of deposits is not negligible too. The higher temperature region experienced severe deposit-induced corrosion or hot corrosion, where the melting temperature of the deposits was 524$683{ }^{\circ} \mathrm{C}$. A thick deposit could decrease corrosion rates by reducing surface temperatures, protecting it from further active oxidation and preventing the volatilization of metal chlorides. However, this is valid only if the deposit has not melted [2]. Also structural changes of materials can occur in these conditions, e. g. precipitation of carbides or other phases in stainless steels increases sensitization to intergranular corrosion, decarburization of surface layers in unalloyed steel changes their mechanical properties [4-6]. The corrosion damage is supported by solid particles erosion in flue gas. The average rate of the turbulent flue gas flow is approximately $5 \mathrm{~m} . \mathrm{s}^{-1}$.
The chemical composition of environment is responsible for character of resultant corrosion products. Present oxygen creates with $\mathrm{Fe}$ alloys (low or high alloyed) oxides mostly with protective character and especially with the elements $\mathrm{Cr}, \mathrm{Al}, \mathrm{Si}$. The sulphur compounds $\left(\mathrm{H}_{2} \mathrm{~S}, \mathrm{SO}_{2}\right)$ are unwanted because sulphides do not have protective properties, create eutectics and increase corrosion rate. Halides (Cl-, F-) freeing during $\mathrm{Al}$ waste combustion are very aggressive corrosive agents and support corrosive effect of sulphur compounds too [7 and 1]. During the reclaim process, besides the mentioned agents, other components present can produce e. g. carbon and nitrogen oxides, dust gases, organic compounds (VOC - volatile organic compound, dioxin). The mentioned compounds increase corrosion aggressiveness of the work environment. The next factors affecting corrosion and mechanical properties of Fe and $\mathrm{Ni}$ alloys in the duct system are hydrogen, $\mathrm{CO}$, hydrocarbons [6, 1 and 8]. Consequently high-temperature corrosion in so complicated conditions can be amplified by a range of factors: chemical composition of flue gas erased in the $\mathrm{Al}$ produced furniture; fluctuations in the flue gas flow; the high velocity, particle-bearing flue gas; and finally deposit (combustion residues) accumulation [9 and 11].

\section{Experimental part}

\section{Experimental material}

Because of impossibility to specify exactly the chemical composition of the work environment in the duct system of the recycling Al furnace, three types of alloys were chosen for the experiment in the real conditions. The experimental material was chosen according to actual science references [2,9 and 10] and experiences of

\footnotetext{
${ }^{*}$ Tatiana Liptakova ${ }^{1}$, Jozef Jandacka ${ }^{2}$, Milan Malcho ${ }^{2}$, Michaela Vojsovicova ${ }^{1}$

${ }^{1}$ Department of Materials Engineering, Faculty of Mechanical Engineering, University of Zilina, Slovakia, E-mail: tatiana.liptakova@fstroj.uniza.sk

${ }^{2}$ Department of Power Engineering, Faculty of Mechanical Engineering, University of Zilina, Slovakia
} 


\section{COMMNICOIIONS}

Chemical composition of the experimental material

Tab. 1

\begin{tabular}{|c|c|c|c|c|c|c|c|c|c|c|c|c|c|}
\hline Element (wt. \%) & $\mathrm{Cr}$ & $\mathrm{Ni}$ & $\mathrm{Mo}$ & $\mathrm{Mn}$ & $\mathrm{N}$ & $\mathrm{Ti}$ & $\mathrm{C}$ & $\mathrm{Si}$ & $\mathrm{P}$ & $\mathrm{S}$ & $\mathrm{W}$ & $\mathrm{Co}$ & $\mathrm{Fe}$ \\
\hline AISI $316 \mathrm{Ti}$ & 16.5 & 10.6 & 2.12 & 1.69 & 0.012 & 0.41 & 0.04 & 0.43 & 0.026 & 0.002 & & & rest \\
\hline STN 411357 & & & & & 0.009 & & 0.17 & & $<0.045$ & 0.045 & & & rest \\
\hline Ni based alloy & 1.88 & 71.47 & 7.30 & 0.09 & & 1.075 & $<0.001$ & $<0.001$ & & & 9.5 & 7.98 & rest \\
\hline
\end{tabular}

operator: unalloyed steel (STN 41 1357.21), stainless steel (AISI 316Ti) and Ni based alloy. The chemical composition of experimental material is in Tab. 1.

\section{Experimental specification}

The experimental samples were fastened to the wall of the duct system and exposed one year in real operating conditions of the aluminium furnace. Before the experiment the samples were mechanically cleaned, ungreased by ether and after drying weighed with the accuracy $10^{-5} \mathrm{~g}$. The first sample set was situated in the duct system inlet where temperature varies from 650 to $850{ }^{\circ} \mathrm{C}$,

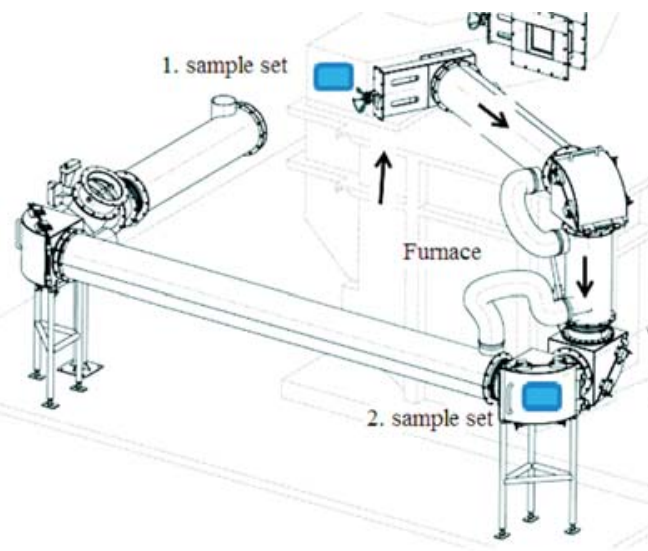

Fig. 1 Scheme of the furnace, location of samples and direction of gas flow and the second sample set was situated in the duct system exit where the temperature varies from 250 to $300{ }^{\circ} \mathrm{C}$ as it can be seen in Fig 1. The direction of flue gas flow is marked by arrows in the same picture. The real temperature history during operation in the duct system is in Fig. 2.

\section{Results and discussion}

After one year exposition the weight losses were measured and corrosion rate calculated. Character and intensity of corrosion attack was investigated by light microscopy and visually.

\section{Weight loss analysis}

The results of our experiment confirmed very high aggressiveness (chemical composition, flow and temperature) in the duct system inlet of the alumina furnace. The samples localized in the duct system inlet after 1 year of exposition disappeared and it means that in this part of the duct system the metal is very strongly damaged by corrosion and erosion. Only negligible rest of unalloyed steel remained under the fixing screw. The damage of the metals tested in the same condition for 30 days confirmed higher corrosion - erosion effect in the duct system inlet in comparison with outlet too [10]. Norling et al [9] investigated the erosion-corrosion behaviour of two steels AISI 304, $353 \mathrm{MA}$ ) and one Ni-based super alloy (Inconel 625). The alloys were exposed in a test rig at $550{ }^{\circ} \mathrm{C}$ in air for 1 day, 1 and 3 weeks. The particle velocity was $1.2 \mathrm{~m} / \mathrm{s}$. The measured wastage of the alloys was in the range 58$270 \mu \mathrm{m} / 1000 \mathrm{~h}$. [9]. According to our investigation the original thickness of the unalloyed steel was $8 \mathrm{~mm}$, stainless steel $3 \mathrm{~mm}$ and $\mathrm{Ni}$ based alloy $4 \mathrm{~mm}$. It means that in the duct system inlet is cor-

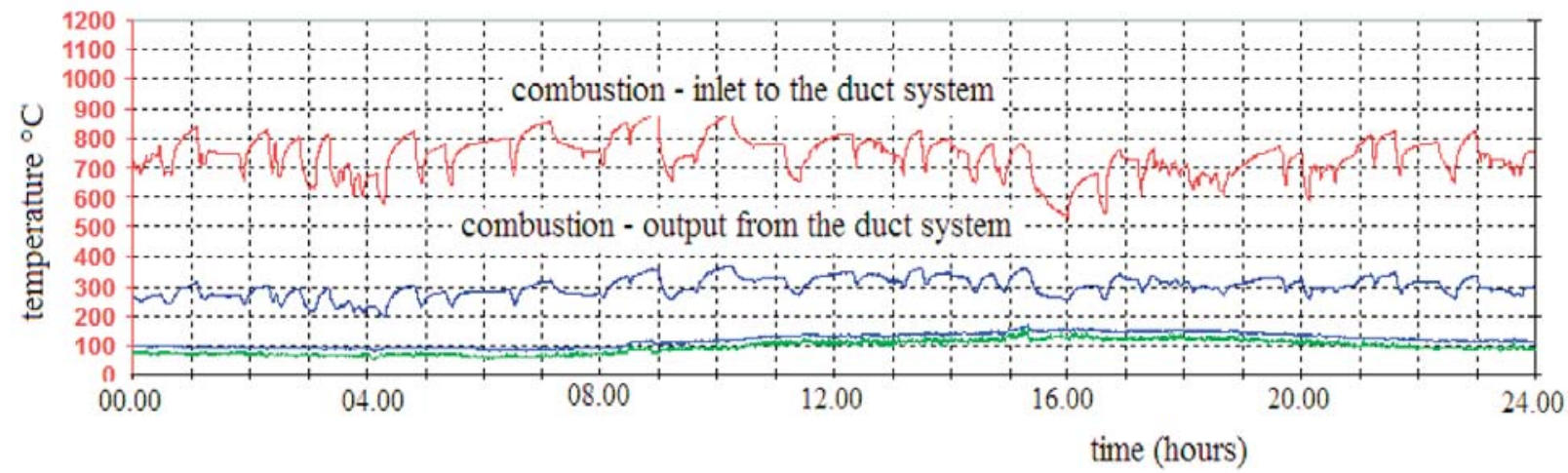

Fig. 2 Time diagram of temperature history during 24 hours operation in the duct system 

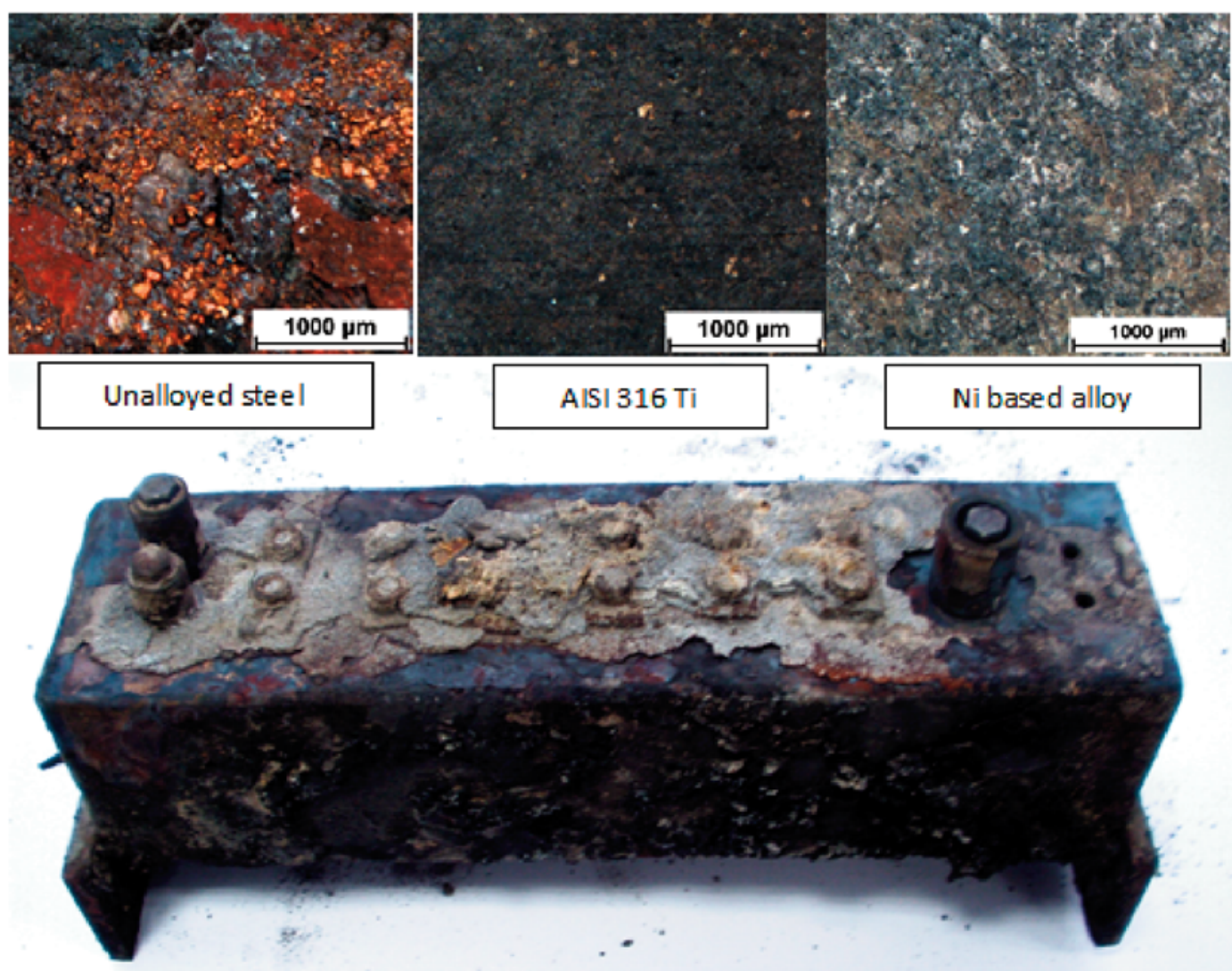

Fig. 3 Deposits on the tested sample in the duct system after exposition and surfaces of the tested metals after deposit removing

rosion-erosion wastage of unalloyed steel $913 \mu \mathrm{m} / 1000 \mathrm{~h}$. and $\mathrm{Ni}$ based alloy $456 \mu \mathrm{m} / 1000 \mathrm{~h}$. According to the results in the outlet, the stainless steel corrosion-erosion wastage is approximately 600 $\mu \mathrm{m} / 1000 \mathrm{~h}$. The samples fixed in the duct system outlet were covered by the thick layer of deposits (Fig 3). The deposits in this part of duct system create a partial protection mainly to erosion because the deposits content pores and cracks where corrosion agents have access. But they are during furnace operation two times in a year removed for heat transfer. The surfaces of the tested materials after deposit removing are in Fig. 3.

After removing the deposits of unalloyed steel under the inhomogeneous deposits there were strong adhering dark grey-brown corrosion products. Corrosion products created at high temperature have protective effect. The deposits were mechanically removed and the corrosion products were chemically eliminated in the solution of the $20 \% \mathrm{HCl}+3.5 \mathrm{~g}$ hexamethylenetetramine per $\mathrm{dm}^{3}$ of the solution for 3 minutes at temperature of $22{ }^{\circ} \mathrm{C}$. The samples were in the initial shape and it demonstrates that on the both sites of the duct system there were different operating conditions. The cleaned and dried samples were weighted again. From the weight differences before and after exposition the weight losses per the area were calculated $\left(v_{k}\right)$. The corrosion attack depth is substantiated from metalography investigation. The gravimetric analysis results are presented in Tab. 2 as well as average depth of attack
Weight losses of unalloyed steel are higher in order in comparison to stainless steel and high Ni based alloy. But the total depth of the stainless steel and high Ni alloy corrosion is not clear from the weight analysis. To take the weight analysis results into consideration it can be said that corrosion resistance of the tested metals is significantly different.

Rate and depth of corrosion attack after exposure

Tab. 2

\begin{tabular}{|c|c|c|}
\hline Sample & $v_{k}\left({\left.\mathrm{~g} . \mathrm{m}^{-2} \mathrm{y}^{-1}\right)}^{\text {Depth of corrosion }}\right.$ & attack $(\mu \mathrm{m})$ \\
\hline STN 426317.31 41 1357 & 144.00 & 10 \\
\hline AISI 316Ti & 24.00 & 20 \\
\hline High alloy Ni & 11.40 & 15 \\
\hline
\end{tabular}

Microscopic analysis

The samples were cross-cut, sealed to resin, grinded, polished and etched. On the prepared samples the structure, character and intensity of corrosion attack are investigated. s. The corrosion attack after 1 year exposition in the aluminium furnace was investigated on the etched samples (the unalloyed steel by the Nital, 
the stainless steel by the Rollings $\left(\mathrm{CuCl}_{2}+\mathrm{HCl}+\right.$ ethanol/, the $\mathrm{Ni}$ based alloy by the $\mathrm{BR}\left(\mathrm{HNO}_{3}+\mathrm{HF}+\right.$ glycerine $)$. The differences of corrosion attack intensity determined by gravimetric and microscopic analysis are caused by different corrosion behaviour of the tested metals.

The samples of unalloyed steel are attacked by general corrosion started on the grain boundaries. The high temperature oxides are brittle and during operation cracks are created and it makes possible access of corrosion agents to bare metal [12]. Corrosion damage of the unalloyed steel surface is supported by mechanical effect of the flue flow containing solid particle (Fig. 4). In the depth about $100 \mu \mathrm{m}$ from the surface light decarburization is observed. In Fig. 5 it can be compared damage of the same material after 30 days in the duct system inlet. Higher temperature causes stronger corrosion attack, decarburization (about $200 \mu \mathrm{m}$ ) and increment of the grains in the place where the sample was deformed. High

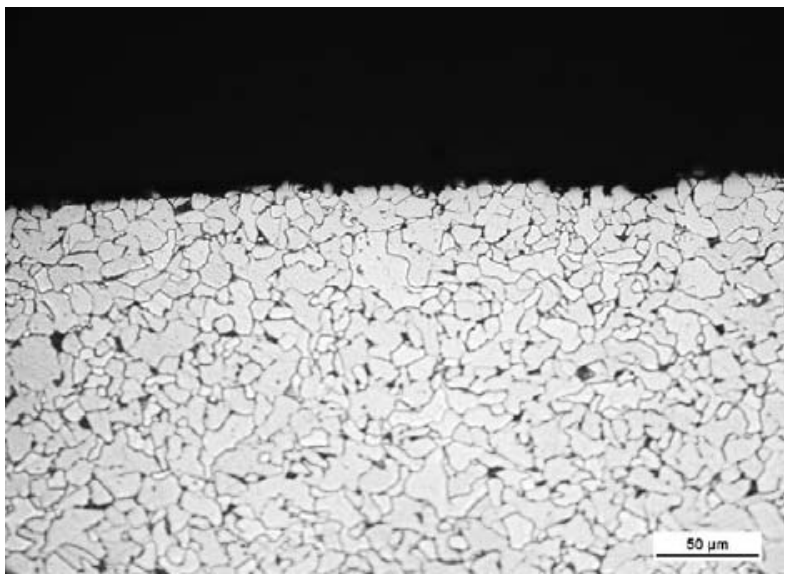

Fig. 4 Surface of the steel STN 411357.21 in the duct system outlet after 1 year exposition, mag.400, etch.Nital

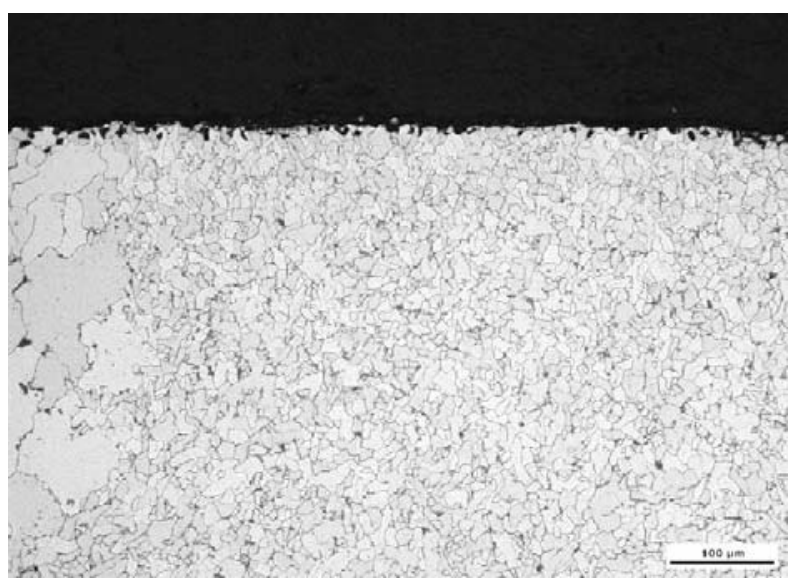

Fig. 5 Surface of the steel STN 411357.21 in the duct system inlet after 30 days exposition, mag. 200, etch.Nital temperature can change in the metals: structure, various phase formation, corrosion thermodynamics and kinetics, character of corrosion products and deposits. The actualities intensively worsen corrosion-erosion damage of material in the duct system inlet.

The corrosion products of the AISI 316Ti after one year exposure in the duct system outlet were inhomogeneous of dark grey colour with good adhesiveness. By microscope analysis the general inhomogeneous corrosion was identified (Fig. 6a). The corrosion attack of the steel AISI 316Ti after 30 days of exposition in the duct system inlet is shown in Fig 6b. Under the deposits the passive layer ability of renovating is reduced and the cracks are present in oxide film The corrosion starts on the grain boundaries and the grains are removed by corrosion-erosion effect. The changes in the oxide layers during high-temperature oxidation were determined by Norling et al [9]. They identified oxide crushes and cracks on the surface of oxide layers. It is concluded that only the oxide scale is eroded and that the erosion takes place by chipping of small fragments from the oxide surface. The energy of the bombarding particles is not high enough to remove the oxide down to the oxide/metal interface. The thin oxide is free of cracks and pores and covers the
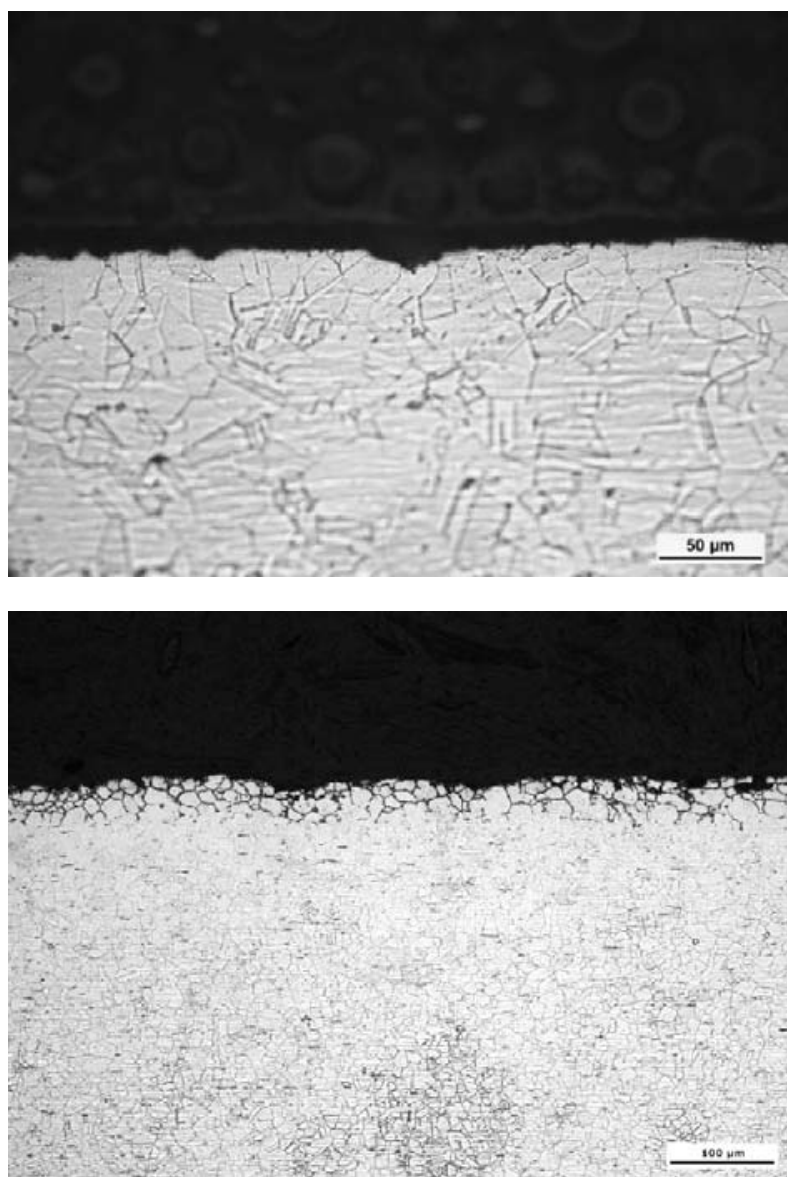

Fig. 6 Damage of the AISI 316Ti after 1 year exposition in the duct system outlet (a), mag. 400, and after 30 days in the duct system inlet (b), mag. 200, etch. Rollings 
surface entirely [ 9 and 3]. It is supposed that the aggressive agent from the flue gas penetrates to the bare metal and it starts corrosion preferentially in the grain boundaries area.

The nickel-based alloys had lower corrosion rates than the iron-based alloy in combustion environment at higher temperature. They were, however, more prone to localised corrosion, most notably from alkali-metal chlorides, and had a lower resistance against pits and crevices [9]. The Ni based alloy shows after our experiments the best corrosion-erosion properties in comparison with unalloyed and stainless steel. The corrosion products of the
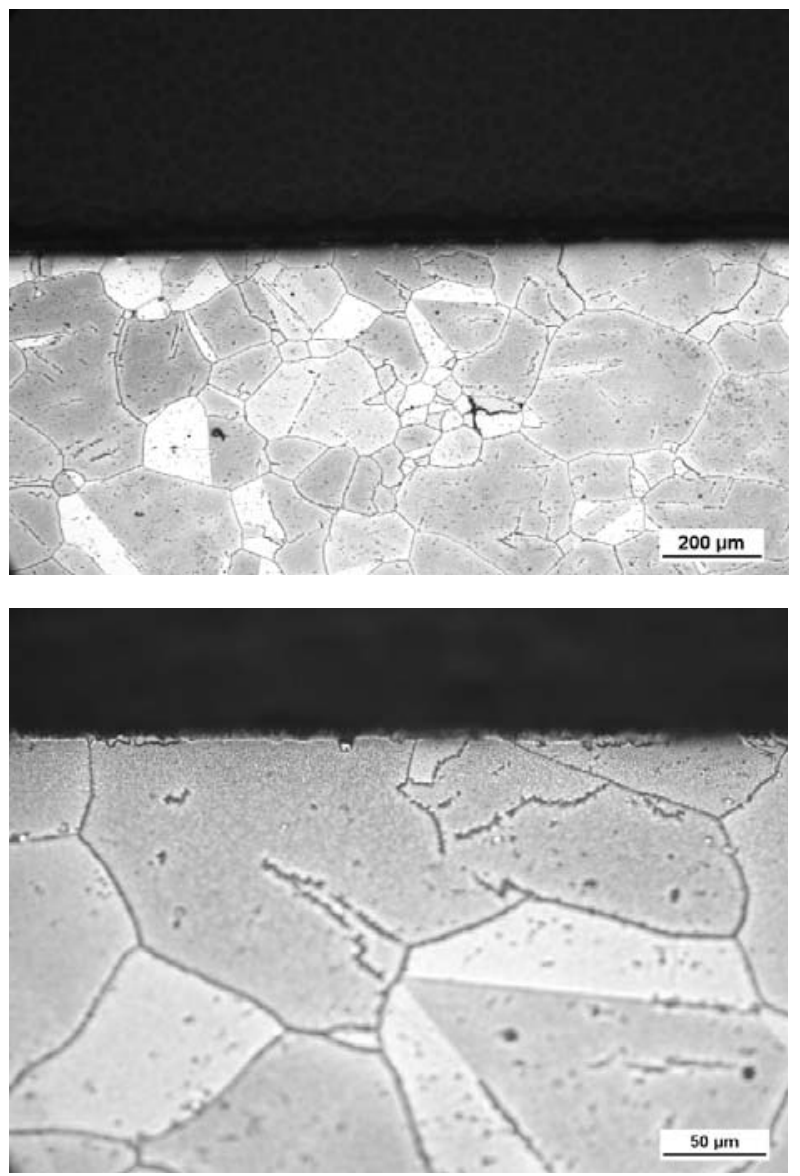

Fig. 7 Corrosion-erosion damage of the high Ni alloy after 1 year exposition in the duct system outlet, mag. 100, and mag. 400 etch. BR
Ni based alloy are dark grey colour with good adhesiveness. Local corrosion reaches only a few $\mu$ m under the surface as it can be seen in Fig. 7. Occasionally in subsurface the grain boundary oxidation was observed. Our results are in very good agreement with the results published in [9] and [11] where authors investigated wastage of similar materials at high temperature.

\section{Conclusions}

On the basis of realized experiments and analyses, we concluded:

- All the tested materials were damaged by various intensity of corrosion-erosion in the duct system inlet and outlet. In the duct system inlet the average temperature is about $800{ }^{\circ} \mathrm{C}$ and it enhances corrosion rate and changes behaviour of the deposits. The samples from the inlet with the thickness between 3 and 8 $\mathrm{mm}$ were completely damaged. This fact indicates the very high aggressiveness of the environment in the duct system inlet.

- The temperature drop in the duct system outlet (about $300{ }^{\circ} \mathrm{C}$ ) presents decreasing of the testing metal materials wastage lower by two orders.

- According to the weight analysis results the best corrosion-erosion resistance has the Ni based alloy, $\mathrm{Cr}-\mathrm{Ni}$ alloyed steel has two times lower and unalloyed steel has about ten times lower than stainless steel.

- Corrosion-erosion attack depth of the tested materials in the duct system outlet evaluated by microscopy is negligible after one year of exposition.

- The different corrosion-erosion damage in the inlet and outlet of the duct system suggest variouscorrosion mechanism and kinetics caused by different temperature.

- Grain thickening at the surface areas occurred only in unalloyed materials in the duct systeminlet, especially in steel deformation locality. Strain tension in this area is reduced by recrystallization at high temperature.

The experimental results can help as an effective tool for duct system material selection. The metals selection for the duct system construction has to be made with respect to production efficiency. Therefore it is necessary to take into consideration not only corrosion-erosion resistance but the price of material too.

\section{Acknowledgement}

This research was supported partially by the grant VEGA No. 1/0066/11. Authors gratefully acknowledge this support.

\section{References}

[1] MOLNAR, L., VIRCIKOVA, E.: Charakteristika emisii znecistujucich latok z technologie pretavovania hlinikových odpadov [Characteristics of Pollutant Emission from the Remelting Aluminium Waste Technology], Acta Montanistica Slovaca, vol. 10, No. 1, 2005, pp. 220-23.

[2] HOWES, T. E., ROGERS, P. M., LITTLE, J. A., HUTCHINGS, I. M.: Erosion-corrosion of Mild Steel in a Temperature Gradient, Wear1 86187, 1995, pp. 316-324 
[3] ENTWISLE, M. J., GIBB, J., HUTCHINGS, I. M., LITTLE, J. A., MEADOWCROFT, D. B., NINHAM A.J., OAKEY J. AND SIMMS N.: In E. Bachelet et al. (eds.), The Laboratory Simulation of Fluidized Bed Tube Wastage, High Temperature Materials for Power Engineering, Kluwer, Dordrecht, 1990, pp. 239-248.

[4] PHONGPHIPHAT, A, RYU, CH, YANG, Y. B. A, FINNEY, K. N., LEYLAND, A., SHARIFI, V. N., SWITHENBANK, J., DAVIS, J. R: ASM Speciality Handbook, Heat Resistant Materials, USA, ISBN 0871705966, 1997.

[5] BIRKS, N. et al: High Temperature Oxidation of Metals, $2^{\text {nd }}$ edition, Cambridge University Press, 2006, ISBN-13 978-0-521-48042-0

[6] KHANA, A., S.: High Temperature Oxidation and Corrosion, ASM International, USA 2002, ISBN 0-87170-762-4.

[7] HADZIMA B., LIPTAKOVA, T.: Zaklady elektrochemickej korozie kovov [Fundamentals of Electrochemical Metal Corrosion], EDIS ZU Zilina, 2008. ISBN 978-80-8070-876-4.

[8] CERNY M. et al: Korozni vlastnosti kovovych konstrukcnich materialu [Corrosion Properties of Metal Construction Materials], SNTL Praha, 1984.

[9] NORLING, R., OLEFJORD, I.: Erosion-Corrosion of Fe- and Ni-based Alloys at 550 ${ }^{\circ} \mathrm{C}$, Wear 254, 2003, pp. $173-184$.

[10] LIPTAKOVA, T., MALCHO, M., JANDACKA, J.: Corrosion Behaviour of Chosen Construction Metals in the Duct System of the Recycling Aluminium Furnace, Material Engineering, vol. 17, No. 3, 2010, pp. 28-34.

[11] PHONGPHIPHAT, A., CHANGKOOK, RYU YAO, BIN, YANG, FINNEY, K. N., LEYLAND, A., SHARIFI, V. N., SWITHENBANK, J.: Investigation into High-temperature Corrosion in a Large-scale Municipal Waste-to-energy Plant, Corrosion Science 52, 2010, pp. 3861-3874.

[12] HIDAKA Y., ANRAKU, T., OTSUKA, N.: Deformation of Iron Oxide Scales Upon Tensile Tests at 700-1280 •, In: Abstract Booklet of $5^{\text {th }}$ Intern. Symposium on High Temperature Corrosion and Protection of Materials, Les Embiez, France, 2000 (pp. 4-A115). 